\title{
CODE SWITCHING UTTERANCES OF PUBLIC FIGURES' VLOG IN YOUTUBE CHANNEL
}

\author{
Halimah Tussa'diah', Eka Anggaini², Selamat Husni Hasibuan ${ }^{3}$ \\ 1,2,3 University of Muhammadiyah Sumatera Utara \\ ${ }^{1}$ halimmaht@umsu.ac.id, ${ }^{2}$ ekaanggaini@yahoo.com, ${ }^{3}$ selamathusni@umsu.ac.id
}

\begin{abstract}
This research dealt with the analysis of Code-Switching Utterances of Public Figures' Vlog In YouTube Channel. The objectives were to determine code-switching and the types of code-switching used by the public figures and the guests. The researcher focused on the application of Intra- sentential (74 cases), Inter-sentential (85 cases) and Extra/Tag code-switching (26 cases). A descriptive qualitative method was taken to analyze the data from four videos on YouTube published in March 2019 until November 2019. The finding showed that public figures and the guests used code-switching, which included 185 cases. There were seven reasons of public figures switched the language; 75 data of talking about a particular topic, 2 data of quoting somebody else, 1 data of being emphatic about something, 13 data of interjection (inserting sentence filler or sentence connector), 27 data of repetition of clarification, 63 data of intention for clarifying the speech content for the interlocutor, and 4 data of expressing group identity.
\end{abstract}

Keywords: Code Switching, Utterances, Descriptive Qualitative

\section{INTRODUCTION}

Media and society are bound to each other. That is because the media contains events that occur in older people. The impact of media in life is enormous. It gives information to people. The information in the media is beneficial to the readers and listeners. Then, it is considered as a human need. It can be knowledge, awareness, educating towards the community, a job, etc. Media plays an essential role in human life.

Communication refers to the process of exchanging information among individuals, groups, institution, or organizations in oral, written or signed forms through any available media. Magazine, newspaper, letters and other kinds of printed forms are regarded as written communication (Nowogbaga, Nwankwo and Onawa in Kristin \& Kathryn, 2018: 377). Spoken or oral communication means that people use mouth to speak or deliver information. It can be found on television, YouTube, and social media. Those have purposes of sharing ideas, daily activity, feeling, creativity, emotions, disaster, tragedy, job and others with someone else.

In social life in Indonesia, English is not so stranger to be heard. Many people compete in learning English because it is also a necessity in the world of work. Not only that, but English is also used for style among young people to make it slang in speaking. Public figures as well often use it as a second language. From this case, the speakers often encounter deliberate or unintentional language changes between Indonesian and English. This changing language is called code-switching. According to Hymes (in Fitrah 2017; 31), whenever people deliver their conversation in more than one language, it means code-switching happens in their communication. 
Dedy Corbuzier and Boy William are public figures in Indonesia. These public figures are active in the world of entertainment and social media. The researcher chose the world of social media; YouTube. Public Figures are more active in social media, primarily due to the Covid19 case that requires work from home all over the world. It was a reference for the researcher to find code-switching cases because Dedy Corbuzier and Boy William are bilingual people or people who can speak two languages. Code-switching occurred when talking with the guests in their videos. As public figures, they have a YouTube channel. This channel is a work area for sharing information, including personal problems and beyond it. It becomes an interaction with fans and viewers when interacting. When the public figures talk with the guests, they often change the language. The language shift becomes a trend to other public figures to appear feeling of engagement and friendliness. The speaker must be prepared to make claims to persuade their main audiences (Husni, 2020). That was a reason for the researcher to choose them as the data to identify the utterances and reasons spoken by public figures in their vlogs.

Every utterance has its categories ranging from words, phrases, and clauses. The researcher wanted to find code-switching towards public figures and guests. According to Poplack (in Aisha 2018; 95), that code-switching covers Tag-switching (insertion of a tag phrase from one language into an utterance of another language), Inter-sentential switching (insertion at a clause or sentence boundary), Intra-sentential switching (insertion within the clause or sentence). The researcher made categories of the utterances of the speakers in the video towards the types of code-switching.

\section{Bilingualism}

Bilingualism is a person who can master two or more two languages. Braun 1937 cited in Margana $(2015 ; 336)$ that bilingualism refers to a fluent person in more than one languages, Haugen cited in Margana (2015) also states that a bilingual speaks other languages equally as his/her native language. A person is called a bilingual since he learns the second language or foreign language or something the speaker needs to master the second language.

Nowadays, bilingualism is not strange in society life. Social interaction also requires language to achieve communication needs. A bilingual often replace the original language with another language. The reason is to achieve communication goals. The change of language can also be supported by other factors such as the foreigner to speak. So the speaker must use an international language to share information or other things.

\section{Code-Switching}

Code-switching means things that people share about the trivial or formal conversation in certain communicative events in which the bilingualism or multilingual are involved (Nguyen in, Alhourani, 2018: 11). It means that these cases usually happen in social life and it is usually used in a formal and informal situation.

Switching language involves the mastery of two or more languages. Code-switching often exists in daily conversation whenever people are involved in a conversation about educational, ethical, and socioeconomic backgrounds. It is avoided in a formal speech situation among people, especially those who have little in common factors in terms of socioeconomic status. Again, Hornberger and McKay in Widi $(2020 ; 138)$ clarifies that code-switching is applied by people in daily interaction in which they often change their code from one language to another language. Code-switching happens in a conversation between two speakers. In the latter case, it can occur between sentence (inter- sentential) or within a single sentence (intra- sentential). Code-switching can appear from individual choices, or it can be used as a primary identity 
person itself. According to Poplack, code-switching consists of Inter-sentential switching (when a speaker speaks clause in one language, and then he uses different clause in a different language). It is a complete sentence in which the utterances consist of two different sentences in two different languages. Inter-sentential switching (a switch at a clause or sentence boundary; one clause being in one language, the order clause in the other one), for example: "kemejamu biru langit, I like it", Intra-sentential switching (when a word, a phrase or clause of a foreign language occurs within the sentence in the base language), for example: "apa arti invitation Anak-anak"?, and Extra-sentential switching or tag switching (switching of either a single word or a tag phrase or both from one language to another), for instance, "By the way, si Mila kok belum datang juga ya", the word 'By the way' is a tag-switching.

\section{The Reason for Using Code Switching}

While the code-switching occurred, the motivation or reasons became the background of why the speaker switched language with the interlocutor. Hoffman cited in Wiruma $(2017 ; 43)$ that there are some reasons bilingual speakers switch their language as; Talking about a particular topic, people sometimes prefer to talk about a particular topic in one language rather than in another. Quoting somebody else, the speaker quotes famous expressions or sayings in the original language. Being emphatic about something expresses solidarity ( the speaker either intentionally or unintentionally will switch from his/her second language to the first language). Interjection or inserting sentence fillers or sentence connectors (words or expressions inserted into a sentence to convey surprise, intense emotion, or gain attention), like Damn! Well! Look! Repetition used for clarification (when a bilingual user wants to clarify his/her speech to the interlocutor).

Richard Nordquist states that an utterance means when human vocal organs produce voices started by silence and continued by silence or a change of speakers. Phonemes, morphemes and words are all considered "segments" of the stream of speech sound that constitute an utterance. In linguistic, an utterance is a unit speech. In orthographic terms, an utterance is a syntactic unit that begins with the capital letter and ends in a period, question mark or exclamation point (http://www.thoughtco.com/utterance-speech-1692576, 28 July 2019).

\section{METHOD}

This research applied descriptive design with the qualitative approach as the method to analyze the data - the research directly described in words public figures' utterances in videos on youtube. Descriptive method is a method of research that makes the description of the situation of the event occurrences. So that method has the intention to accumulate the primary data (Sukmadinata, 2017). According to Creswell, J. W. (2012) that qualitative research is inquirer dealing with data. Those are in the form of words or pictures rather than numbers and statistic. So in this research, the researcher did not use numbers to explain or describe the phenomenon but analyze the phenomenon.

The source of the data in this research was utterances. It happened in public figures' vlogs when the speaker and the guest were talking. The data were collected by applying random sampling. It was videos of Dedy Corbuzier and Boy William as the sample on YouTube channel. In those videos, every sample included two videos as the source starting from March 2019 until November 2019 with the title "Agnes mo Menjawab : EXCLUSIVE", "Klarifikasi and Cinta Laura Kiehl : Buat cowo yang mau dekatin dia" (Deddy Corbuzier's channel) and also Boy Wiliam's videos "Maudy Ayunda Di omongin seniornya ketika OSPEK di STANFORD", and "Q\&A Boy Wiliam \& Karen Vendela pertama kalinya". The researcher chose them as the 
source of the data because they could speak English and were very popular on YouTube. In this case, the researcher used note-taking technique. The data would be collected by the following steps, such as:

1) Watching the videos of the vlog as the source of the data.

2) Writing down the utterances to be a transcript which was found in the videos.

The data were analyzed using qualitative analysis. The activities of qualitative analysis consisted of the data reduction. The data were summarized, grouped, and focused on the main one's research problem. The researcher identified the research problem and then classified the main problem from the total data, data display (the researcher categorized the code-switching case according to types of code-switching), and conclusion drawing (The conclusion would be followed by evidence obtained when researching this field, so that the data category could answer overall problems regarding code-switching utterances). This method aimed to present a description systematically, factually, and accurately regarding the nature and relationship of phenomena investigation. This analysis could be carried out when the researcher was in the field by describing.

\section{RESULTS AND DISCUSSION}

\section{Results}

The following was the use of Types

of Code-Switching applied by Public Figures (Boy William and Dedy Cobuzier) with their guesses (Maudy Ayunda, Karen Vendela, Cinta Laura Kiehl, and Agnes Mo), and the reasons for using code-switching:

Table 1. The Percentage of the Types of Code-Switching Utterances

\begin{tabular}{c|l|c|c|c}
\hline No & Name of video & Inter & Intra & Inter \\
\hline 1 & $\begin{array}{l}\text { Q \& A Boy Wiliam \& Karen Vendela: ini alasan Karen yakin } \\
\text { dengan Boy }\end{array}$ & 5 & 6 & 1 \\
\hline 2 & $\begin{array}{l}\text { Maudy Ayunda: di omongin seniornya ketika di OSPEK di } \\
\text { STANFORD }\end{array}$ & 11 & 18 & 5 \\
\hline 3 & Cinta Laura Kiehl: buat cowo yang mau dekatin dia & 37 & 20 & 10 \\
\hline 4 & Agnes Mo Menjawab EXCLUIVE, “Klarifikasi” & 32 & 30 & 10 \\
\hline \multicolumn{2}{c}{ Total } & 85 & 74 & 26 \\
\cline { 2 - 4 } & \multicolumn{3}{c}{185} \\
\hline
\end{tabular}

Table 2. The Percentage of the Reasons of Using Code-Switching

\begin{tabular}{|c|c|c|c|c|c|c|c|c|}
\hline No & Name of video & $\mathbf{A}$ & $\mathbf{B}$ & $\mathbf{C}$ & $\mathbf{D}$ & $\mathbf{E}$ & $\mathbf{F}$ & $\mathbf{G}$ \\
\hline 1 & $\begin{array}{l}\text { Q \& A Boy Wiliam \& Karen Vendela: ini alasan } \\
\text { Karen yakin dengan Boy }\end{array}$ & 12 & 0 & 0 & 0 & 0 & 0 & 0 \\
\hline 2 & $\begin{array}{l}\text { Maudy Ayunda: di omongin seniornya ketika di } \\
\text { OSPEK di STANFORD }\end{array}$ & 21 & 0 & 1 & 2 & 1 & 9 & 0 \\
\hline 3 & Cinta Laura Kiehl: buat cowo yang mau dekatin dia & 20 & 0 & 0 & 3 & 10 & 34 & 0 \\
\hline 4 & Agnes Mo Menjawab EXCLUIVE, "Klarifikasi” & 22 & 2 & 0 & 8 & 16 & 20 & 4 \\
\hline \multirow{2}{*}{\multicolumn{2}{|c|}{ Total }} & 75 & 2 & 1 & 13 & 27 & 63 & 4 \\
\hline & & \multicolumn{7}{|c|}{185} \\
\hline
\end{tabular}




\section{INFORMATION}
A : talking about particular topic
B : quoting somebody else
C : being emphatic about something (expressing solidarity)
D : interjection (inserting sentence filler or sentence connector)
E : repetition used clarification
F : intention for clarifying the speech content for interlocutor)
G : expressing group identity

\section{Discussion}

1. Type of Code-Swtiching

1.1 Inter-sentential switching means that if one speaker conveys an utterance in one language and then he changes the next utterance of his different sentence into a different language. It is a complete sentence which consists of two different sentences in two different languages. In this research, it was found in the public figures' conversation like Boy William with Maudy Ayunda and Karen Vendela, and Dedy Cobuzier with Cinta Laura Kiehl and Agnes Mo, as "Seperti yang kalian tau gua ada di Amerika and today gua mau samperin salah satu temen gua Maudy Ayunda yang lagi kuliah disini di Stanford di Fransisco. I want to check out what she up too. This is my first-time bener ada di pekarangan Stanford. I super excited and I'm here with my family." "Halo ini Boy dan ini ada Karen juga and we here to answer your questions. Kita kemaren di instagram sempet lempar Q \& A. we answer again", "Satu jam dua puluh lima menit (0.1.25) yang harusnya kalau kata GPS 57 menit but totally yes. Jadi udah tau kan, aku orangnya sangat on time and I love schedules things". "Hai... apa kabar ? How are you? Apa kabar? These all expressions showed that there is the switching between Bahasa Indonesia and English or vice versa. The speaker said one language in their sentence, but then they said different languages in their other language in the same conversation. Inter-sentential switching occurred 85 times.

1.2 Intra-sentential switching is if the speaker switches two languages in one sentence, so in one sentence the speaker speaks two languages as found in the following examples of Boy William and Dedy Cobuzier's conversation with their guests: "Iya waktu itu aku bilang so right now doing that business and education and then what's really am yaa aku jadi mahasiswa lagi". "Itu sebenarnya engak papa that's okay cuman kalau gua I don't believe that". "Yaa..dia mengatakan prestatic reason sekarang, nanti kalau udah 40an you gonna wear glasses". "Aku baik I'm good..I'm good..em everything is amazing semuanya baik-baik saja". This type of code-switching was applied 74 times.

1.3 Extra-sentential switching refers to the switching of even a word or a tag phrase. This kind of switching was also described in the vlog of Boy Willian and Dedy Cobuzier. They were as "Terus dia bilang lagi dia sudah nunggu 1 jam. Ok damn". "Elu tu kan terkenal dari kecil pada saat...dulu itu...13 tahun ya, right?"."Wow *shock* oh $\boldsymbol{m y}$ god. Dia berotot damn. "Jadi ini anyways, pokoknya gini kalau buat aku itu gini Ded". After being analyzed, this switching covered 26 times. 
2. The Reasons of Using Code-Switching

2.1 Talking about a particular topic. In the conversation, there were some reasons why the public figures (Boy Wlliam and Dedy Cobuzier) and their guests (Maudy Ayunda, Karen Vendela, Cinta Laura Kiehl, and Agnes Mo) applied code-switching. One of them was because they intended to talk about a particular topic, such as "Kalau aku lagi pengen moment to my self and I want to find spaces study outside this is clear area, and here I go. Ini cantik banget. Here the conversation used code-switching because the speaker wanted to talk about a particular topic. It was a total of 75 times used in this research.

2.2 Quoting somebody else. The speaker applied code-switching because he/she wanted to express utterances, a famous person is saying, or wise word of a well-known figure. $\mathrm{He} /$ she could quote the sayings or expressions in their original form, like "Jadi ini anyways, pokoknya gini kalau buat aku itu gini Ded. What they do and in how they react show me what they made of, what I do and how I react show you what I made $\boldsymbol{o f}$, apa yang mereka lakukan ini menggambarkan pribadinya". There were only two times of this kind of reason applied in this research.

2.3 Being emphatic about something (expressing solidarity). The speaker wanted to show her empathy, but at the same time she also wanted to be convenient, so she switched his language to "Karna kemanapun aku jalan umur 13 tahun ke mall. Whenever maybe bukannya orang bilang hi Cinta atau Cinta". This reason was used once only.

2.4 Interjection (inserting sentence fillers or sentence connectors). The speakers showed their strong feeling, and this condition was stated by using Interjection, like "Terus dia bilang lagi dia sudah nunggu 1 jam. Ok damn". There were 13 times Interjection applied in this research.

2.5 Repetition used for clarification. The bilingualist intended to clarify his/her statement, and he repeated his/her words by using code-switching. Repetition was also expressed to emphasize or amplify a message. Here was the example, "Gitu matahari keluar dikit everyone just out and sitting on the ground duduk-duduk di luar". Based on the analysis of the vlog, this type was found 27 times.

2.6 Intention for clarifying the speech content for the interlocutor. The bilingualists and multilingualists conveyed the messages by modifying their language forms, such as "Why do you think like that? Kog seperti itu? I mean people really...elu ngomong gitu karna Cinta? Kenapa Cinta ngomong gitu? The conversation in the vlog contained 63 times the use of this type.

2.7 Expressing group identity. This reason meant that every community had its way of communication which differentiated them, as seen in this expression "dan ini elu disuruh pilih WNI atau dapat Green Card di Amerika". There were four reasons for the use of Expressing group identity in the vlog.

\section{CONCLUSION}

After analyzing the data, the conclusion could be taken as follows:

1. Code-switching was when the speakers deliberately changed a code being used, namely by switching from one to another. There were three types of code-switching; Intersentential, Intra-sentential and Extra/Tag Code switching. Code-switching could occur quite frequently in a formal and also formal conversation among people.

2. The Code-switching occurred if the person could speak two or more languages. The person who could master two or more languages was called bilingualism. 
3. Code-switching case took place in conversation between public figures and the guests in vlogs. It meant that code-switching probably happened if the speaker had a partner in the conversation.

4. There were some reasons for using code-switching; they were talking about a particular topic, Quoting somebody else, Being emphatic about something (express solidarity), Interjection (inserting sentence filler or sentence connector), Repetition used for clarification, Intention for clarifying the speech content for the interlocutor and Expressing group identity.

\section{ACKNOWLEDGMENTS}

Alhamdulillah and forever Alhamdulullah is always the first word to express our thank to The Almighty Allah SWT for the chances and goodness he has given to us. Sholawat and Salam we utter to our Prophet Muhammad SA W who has guided us from the darkness to the light of knowledge. This is the very opportunity the writers wait to participate to join LPPM IKIP Siliwangi, and to this approval we would like to say thank you. Nothing we hope but that our writing can be one of the writings which can give benefit and motivation to the readers and our world education. May Allah always gives His Berkah in all aspects of our live. Aamiin.

\section{REFERENCES}

Abdely, N. A. (2016). Types and Fuctions of Code Switching in the English Language used by Iraqi Doctors in Formal Setting. International Journal of Advenced Research and Review, 10-18.

Aljourani, D. A. (2018). Code Switching as a Communicative Strategy for the Bilingual Saudi Speakers at Jouf University. International Journal of Linguistic, Literature and Translation (IJLLT), 63 - 72 .

Ansar, F. A. (2017). Code Switching and Code Mixing in Teaching Learning Process. Jurnal Tadris Bahasa Inggris , 29-45.

Creswell, J. W. (2012). Educational Research. New York : Phoenix color Cap.

Ekalaya, C. D. (2018). An Analysis of Outer Code Switching and Code Mixing in Indoensia LAWYERS CLUB. Literary Criticism Journal , 49 - 63.

Hasibuan, S. H., \& Manurung, I. D. (2020). Examining Argument Elements and Logical Fallacies of English Education Students in Oral Discussion. Tell: Teaching of English Language and Literature Journal, 8(2), 57.

Kujanen, A. M. (2018). Vlogging in Toronto: Learning Fininsh through Collaborative Encounters. EURO CALL , 214 - 219.

Lubniewski, K. N. (2018). Use of Communication and Technology Among Education professional and Families. Iejee , 377-384

Margana. (2015). Establishing English-Indonesian Bilingual in Indonesia: From Theory to Practice. RA Journal of Applied Research, 365-374.

Martiana, T. (2013). EXamining Code Switching Practices in Hilman Hariwijaya's Makhluk manis dalam Bis dan Bunga untuk Poppi. Passage , 9-20.

Muin, A. (2017). Code Switching as a Communication Strategy. Jurnal Adabiyah , 264 276.

Nwogbaga, David M. E. Nwankwo, Oliver U. Onawa, Doris O. (2015). Avoiding School Management Conflict and crisis through Formal Communication . Journal of Education and Practice, 33.

Prabowo, Y. A. (n.d.). The Patternas of Code Switching Among Youtubers . 1 - 8.

Sugiono. (2018). Metode Penelitian Kuantitatif, Kualitatif, dan $R \& D$. Bandung : Alfabeta. 
Widi Astani, Dwi Rukmini and Djoko Sutopo. (2020). The Impact of Code Switching in Conversation of "Nebeng Boy" Youtube Vlogs Towards Communication in English Among The Participants. UNNES , 182-189. 